\title{
Perbandingan Implementasi Prinsip Good Corporate Governance pada Bank Konvensional dan Bank Syariah
}

\author{
ANDREW SHANDY UTAMA \\ Fakultas Hukum Universitas Lancang Kuning Pekanbaru \\ Jalan Yos Sudarso KM.8 Rumbai \\ Telp. (0761) 51877, Email: andrewshandyutama@yahoo.com
}

\begin{abstract}
In principle, the relationship between the bank and its customers are saving money in the bank based on the relationship of trust, so that each bank is required to have to continue to maintain the level of health. Solutions that can be taken by the banks, both conventional banks and Islamic banks, to maintain the existence and level of health is with the implementation of the principles of good corporate governance. Therefore, it is interesting to examine the comparison of implementation of the principles of good corporate governance in conventional banks and Islamic banks. The method used in this study is a normative legal research. This research use approach legislation. The results showed that in essence, the implementation of the principles of good corporate governance in conventional banks and Islamic banks are the 'same', because it refers to the "Code of Good Corporate Governance Indonesian Banking" issued by the National Committee on Governance (NCG). The fundamental difference lies in Islamic principles used by Islamic banks. In addition to guided and supervised by the Financial Services Authority as conventional banks, Islamic banks are also supervised by the National Sharia Board MUI and Sharia Supervisory Board who served in each Islamic bank.
\end{abstract}

Keywords: The Principles of Good Corporate Governance

Di Indonesia, sebagaimana diamanatkan oleh Pancasila dan Undang-Undang Dasar Negara Republik Indonesia Tahun 1945, tujuan pembangunan nasional adalah terciptanya masyarakat adil dan makmur berdasarkan demokrasi ekonomi dengan mengembangkan sistem ekonomi yang berkeadilan. Untuk menjamin berlangsungnya demokrasi ekonomi, maka segala potensi, inisiatif, dan daya kreasi rakyat wajib dimobilisasikan dan dikembangkan sepenuhnya dalam batas-batas yang tidak merugikan kepentingan umum, sehingga dengan demikian, segala kekuatan ekonomi potensial dapat dikerahkan menjadi kekuatan ekonomi riil bagi kemanfaatan peningkatan kemakmuran rakyat.

Guna mencapai tujuan tersebut, maka pelaksanaan pembangunan ekonomi harus lebih memperhatikan keselarasan, keserasian, dan keseimbangan unsur-unsur pemerataan pembangunan, pertumbuhan ekonomi, dan stabilitas nasional. Salah satu sarana yang mempunyai peran strategis dalam menyerasikan, menyelaraskan, dan menyeimbangkan masing-masing unsur dari trilogi pembangunan tersebut adalah perbankan.

Secara sederhana, bank diartikan sebagai lembaga keuangan yang kegiatan usahanya adalah menghimpun dana dari masyarakat dan menyalurkan kembali dana tersebut ke masyarakat, serta memberikan jasa-jasa bank lainnya. (Kasmir, 2012) Dari segi cara menentukan harga, bank dibedakan menjadi dua jenis, yaitu bank konvensional dan bank syariah. Bank konvensional adalah bank yang menjalankan kegiatan usahanya secara konvensional dan menerapkan bunga. Sedangkan bank syariah adalah bank yang menjalankan kegiatan usahanya berdasarkan prinsip syariah menggunakan sistem bagi hasil dan bebas dari riba. (Muhammad, 2005)

Bagi masyarakat yang hidup di negaranegara maju, seperti di Eropa dan di Amerika, mendengar kata "bank" sudah bukan merupakan barang yang asing. Bank merupakan mitra dalam rangka memenuhi semua kebutuhan keuangan mereka. Bank dijadikan sebagai tempat untuk melakukan 
berbagai transaksi yang berhubungan dengan keuangan. (Kasmir, 2012) Sedangkan di negara berkembang, seperti di Indonesia, pemahaman masyarakat tentang bank masih sedikit, masih terbatas pada masyarakat di perkotaan. Bagi masyarakat di pedesaan, pemahaman tentang bank masih sangat minim, bahkan masih ada masyarakat yang tidak mengetahui sama sekali. (Ismail, 2011)

Pada Pasal 3 Undang-Undang Nomor 7 Tahun 1992 tentang Perbankan, fungsi utama bank adalah sebagai penghimpun dan penyalur dana masyarakat. Pertama, bank berfungsi menghimpun dana dari masyarakat. Bank menghimpun dana dari masyarakat dalam bentuk simpanan. Masyarakat mempercayai bank sebagai tempat yang aman untuk melakukan investasi. Masyarakat yang mempunyai kelebihan dana sangat membutuhkan keberadaan bank untuk menyimpan dananya dengan aman. Dengan menyimpan uangnya di bank, nasabah juga akan mendapatkan keuntungan berupa 'bunga', yang diberikan oleh bank sebagai imbalan. Kedua, bank berfungsi menyalurkan dana kepada masyarakat. Menyalurkan dana merupakan aktivitas yang sangat penting bagi bank, karena bank akan memperoleh pendapatan berupa 'bunga' atas dana yang disalurkan tersebut. Pendapatan yang diperoleh dari aktivitas penyaluran dana kepada nasabah merupakan pendapatan yang terbesar bagi sebuah bank, sehingga kegiatan penyaluran dana menjadi sangat penting. (Ismail, 2011)

Pada Pasal 29 Ayat (2) Undang-Undang Nomor 10 Tahun 1998 ditegaskan bahwa bank wajib memelihara tingkat kesehatan bank sesuai dengan ketentuan kecukupan modal, kualitas aset, kualitas manajemen, likuiditas, rentabilitas, solvabilitas, dan aspek lain yang berhubungan dengan usaha bank, dan wajib melakukan kegiatan usaha sesuai dengan prinsip kehati-hatian. Bank yang tidak sehat bukan hanya membahayakan dirinya sendiri, akan tetapi juga membahayakan kepentingan masyarakat. Hal ini dikarenakan bank mengelola dana masyarakat yang dipercayakan kepadanya dalam bentuk tabungan, deposito, dan giro. Masyarakat sebagai pemilik dana dapat saja menarik simpanannya kapanpun jika mengetahui bank yang menjadi tempat ia menyimpan dana dalam keadaan tidak sehat. Perlu diketahui, tujuan utama masyarakat menyimpan uangnya di bank adalah karena keamanan uangnya terjamin, sedangkan tujuan lainnya adalah untuk berinvestasi, dengan harapan akan memperoleh bunga dari simpanannya tersebut. Pada prinsipnya, hubungan antara bank dengan nasabah yang menyimpan uangnya di bank dilandasi oleh hubungan saling percaya, sehingga setiap bank dituntut harus terus menjaga tingkat kesehatannya.

Masyarakat Indonesia pernah sempat kehilangan kepercayaan terhadap dunia perbankan pada saat krisis ekonomi di tahun 1998 silam, salah satunya yaitu terjadinya penarikan simpanan nasabah secara besarbesaran, terutama di bank-bank swasta. Bukti nyata yang diakibatkan krisis ekonomi tahun 1998 terhadap sektor perbankan yaitu dengan dibekukannya usaha 38 bank, antara lain Bank Ciputra, Bank Ganesha, Bank Pesona, Bank Alfa, Bank Aspac, dan lain sebagainya. Selanjutnya, ada 7 bank yang di-take over oleh pemerintah, yaitu Bank RSI, Bank Putera Sukapura, Bank POS, Bank Artha Pratama, Bank Nusa Nasional, Bank Jaya, dan Bank IFI. Selain itu, juga ada 4 bank pemerintah, yaitu Bank Dagang, Bank Exim, Bank Bumi Daya, dan Bapindo yang dimerger menjadi Bank Mandiri.

Solusi yang dapat ditempuh oleh perbankan di Indonesia untuk tetap menjaga eksistensi dan tingkat kesehatannya adalah dengan implementasi prinsip good corporate governance (GCG), yaitu suatu tata kelola bank yang menerapkan prinsip-prinsip transparancy (keterbukaan), accountability (akuntabilitas), responsibility (pertanggung jawaban), independency (independensi), dan fairness (kewajaran).

Hal yang mengejutkan selama krisis tersebut berlangsung ternyata Bank Muamalat Indonesia ialah salah satu bank yang dikategorikan sehat. Bank Muamalat Indonesia yang pada saat itu merupakan satusatunya bank umum syariah yang ada di Indonesia, ternyata masih dapat 
menunjukkan kinerja yang relatif lebih baik dibandingkan dengan bank-bank konvensional. Saat itu, Bank Muamalat Indonesia mempunyai Capital Adequacy Ratio (CAR) dengan kategori "A". (Anshori, 2009) Melihat fenomena tersebut, maka pada saat ini sebagian besar bank konvensional di Indonesia telah mendirikan bank syariah sebagai pengembangan usahanya, contohnya yaitu berdirinya Bank Syariah Mandiri, BRI Syariah, Bank Mega Syariah, dan lain sebagainya.

Seiring dengan berjalannya waktu, eksistensi perbankan syariah semakin diperkokoh dengan disahkannya undangundang yang khusus mengatur mengenai bank syariah, yaitu Undang-Undang Nomor 21 Tahun 2008 tentang Perbankan Syariah. Hukum pada kenyataannya seringkali ketinggalan dengan perkembangan yang terjadi di masyarakat. Untuk itu, hukum harus bersifat dinamis, yakni mampu mengikuti dan menyesuaikan diri dengan perkembangan masyarakat, khususnya perkembangan di bidang perbankan yang telah mengalami kemajuan yang sangat pesat. Hal ini terlihat jelas dengan belum direvisinya UndangUndang tentang Perbankan. Jadi, dasar hukum lembaga perbankan, terutama bank konvensional, masih mengacu pada UndangUndang Nomor 7 Tahun 1992 dan UndangUndang Nomor 10 Tahun 1998.

Implementasi prinsip good corporate governance pada bank syariah diatur secara tersendiri pada Pasal 34 Ayat (1) UndangUndang Nomor 21 Tahun 2008 tentang Perbankan Syariah, yang menegaskan bahwa bank syariah wajib menerapkan tata kelola yang baik yang mencakup prinsip transparansi, pertanggungjawaban, profesional, dan kewajaran dalam menjalankan kegiatan usahanya.

\section{METODE}

Penelitian ini termasuk jenis penelitian hukum normatif. Penelitian hukum normatif adalah penelitian hukum yang dilakukan dengan cara meneliti bahan pustaka. Dalam penelitian hukum normatif, bahan pustaka merupakan data dasar yang dalam ilmu penelitian digolongkan sebagai data sekunder. Teknik pengumpulan data dalam penelitian ini adalah dengan metode studi dokumenter. Data yang terkumpul selanjutnya dianalisis secara kualitatif dan pada akhirnya disimpulkan dengan metode deduktif.

\section{HASIL}

Berdasarkan analisa perbandingan pada Undang-Undang No. 7 Tahun 1992 tentang Perbankan dan Undang-Undang No. 10 Tahun 1998 tentang Perbankan dengan Undang-Undang No. 21 Tahun 2008 tentang Perbankan Syariah, pada dasarnya, implementasi prinsip good corporate governance pada bank konvensional dan bank syariah adalah 'sama', karena mengacu pada "Pedoman Good Corporate Governance Perbankan Indonesia" yang dikeluarkan oleh Komite Nasional Kebijakan Governance (KNKG). Perbedaan yang mendasar adalah terletak pada prinsip syariah yang digunakan oleh bank syariah. Implementasi prinsip good corporate governance pada bank syariah selain dibina dan diawasi oleh Otoritas Jasa Keuangan seperti bank konvensional, juga diawasi oleh Dewan Syariah Nasional Majelis Ulama Indonesia (MUI) dan Dewan Pengawas Syariah yang bertugas di masing-masing bank syariah.

\section{PEMBAHASAN}

Istilah "good corporate gonernance" pada awalnya muncul sekitar tahun 1970-an di Amerika Serikat setelah terjadi beberapa skandal korporasi dan praktik korupsi yang dilakukan di dalam perusahaan, contohnya kasus Enron dan Worldcom. Prinsip ini lahir karena adanya dorongan dan tuntutan eksternal agar perusahaan tidak melakukan kebohongan publik. Praktik manipulasi data keuangan yang banyak dilakukan oleh perusahaan-perusahaan tersebut jelas merugikan kepentingan publik dan dianggap sebagai tindakan yang illegal, sehingga lahirlah aturan hukum yang dikenal dengan Sarbanes Oxley Act, yang dikhususkan untuk 
mengambil alih fungsi pengawasan atas auditor.

Krisis ekonomi tahun 1998 yang melanda Indonesia membawa efek meningkatnya perhatian dari pemerintah, kalangan pebisnis, serta masyarakat luas terhadap pentingnya penerapan good corporate governance, dan hal ini menjadi isu sentral dalam rangka mendukung pemulihan ekonomi dan pertumbuhan perekonomian yang stabil serta berkelanjutan di masa yang akan datang. Perkembangan kondisi ekonomi yang pesat seiring dengan era globalisasi mendorong setiap perusahaan untuk dapat mengimbanginya. Para pelaku usaha di Indonesia juga turut menyepakati bahwa penerapan good corporate governance sebagai suatu hal yang penting. Hal ini dibuktikan dengan penandatanganan Letter of Intent (LoI) dengan IMF pada tahun 1998, yang kemudian melatarbelakangi lahirnya Komite Nasional Kebijakan Corporate Governance (KNKCG) di tahun 1999. Prinsip good corporate governance mengandung lima prinsip utama, yaitu prinsip keterbukaan (transparency), akuntabilitas (accountability), tanggung jawab (responsibility), independensi (independency), dan kewajaran (fairness).

Bank adalah lembaga intermediasi yang dalam menjalankan kegiatan usahanya bergantung pada dana masyarakat dan kepercayaan, baik dari dalam maupun luar negeri. Dalam menjalankan kegiatan usaha tersebut, bank menghadapi berbagai risiko, baik risiko kredit, risiko pasar, risiko operasional, maupun risiko reputasi. Banyaknya ketentuan yang mengatur sektor perbankan dalam rangka melindungi kepentingan masyarakat menjadikan sektor perbankan sebagai sektor yang 'highly regulated'.

Krisis perbankan di Indonesia yang dimulai pada akhir tahun 1997 bukan sematamata diakibatkan oleh krisis ekonomi, tetapi juga diakibatkan oleh belum dilaksanakannya good corporate governance dan etika yang melandasinya. Oleh karena itu, usaha mengembalikan kepercayaan kepada dunia perbankan Indonesia melalui restrukturisasi dan rekapitalisasi hanya dapat mempunyai dampak jangka panjang dan mendasar apabila disertai tiga tindakan penting lainnya, yaitu ketaatan terhadap prinsip kehati-hatian, pelaksanaan good corporate governance, dan pengawasan yang efektif dari Otoritas Pengawas Bank.

\section{Pelaksanaan good corporate} governance sangat diperlukan untuk membangun kepercayaan masyarakat dan dunia internasional sebagai syarat mutlak bagi dunia perbankan untuk berkembang dengan baik dan sehat. Oleh karena itu, Bank for International Sattlement sebagai lembaga yang mengkaji terus-menerus prinsip kehatihatian yang harus dianut oleh perbankan, telah mengeluarkan pedoman pelaksanaan good corporate governance bagi dunia perbankan secara internasional.

Sebagai lembaga intermediasi dan lembaga kepercayaan, dalam melaksanakan kegiatan usahanya, bank harus menganut prinsip keterbukaan (transparency), memiliki ukuran kinerja dari semua jajaran bank berdasarkan ukuran-ukuran yang konsisten dengan corporate values, sasaran usaha, dan strategi bank sebagai pencerminan akuntabilitas bank (accountability), berpegang pada prudential banking practices dan menjamin dilaksanakannya ketentuan yang berlaku sebagai wujud tanggung jawab bank (responsibility), objektif, dan bebas dari tekanan pihak manapun dalam pengambilan keputusan (independency), serta senantiasa memperhatikan kepentingan seluruh stakeholders berdasarkan azas kesetaraan dan kewajaran (fairness).

\section{Keterbukaan (Transparency)}

Pertama, bank harus mengungkapkan informasi secara tepat waktu, memadai, jelas, akurat, dan dapat diperbandingkan serta mudah diakses oleh stakeholders sesuai dengan haknya. Kedua, informasi yang harus diungkapkan meliputi, tapi tidak terbatas pada hal-hal yang bertalian dengan, visi, misi, sasaran usaha dan strategi perusahaan, kondisi keuangan, susunan dan kompensasi pengurus, pemegang saham pengendali, cross shareholding, pejabat eksekutif, pengelolaan risiko (risk management), sistem pengawasan dan pengendalian intern, status 
kepatuhan, sistem dan pelaksanaan good corporate governance, serta kejadian penting yang dapat mempengaruhi kondisi bank. Ketiga, prinsip keterbukaan yang dianut oleh bank tidak mengurangi kewajiban untuk memenuhi ketentuan rahasia bank sesuai dengan peraturan perundang-undangan yang berlaku, rahasia jabatan, dan hak-hak pribadi. Terakhir, kebijakan bank harus tertulis dan dikomunikasikan kepada pihak yang berkepentingan (stakeholders) dan yang berhak memperoleh informasi tentang kebijakan tersebut. (Komite Nasional Kebijakan Corporate Governance, 2004)

Akuntabilitas (Accountability)

Pertama, bank harus menetapkan tanggung jawab yang jelas dari masingmasing organ organisasi yang selaras dengan visi, misi, sasaran usaha, dan strategi perusahaan. Kedua, bank harus meyakini bahwa semua organ organisasi bank mempunyai kompetensi sesuai dengan tanggung jawabnya dan memahami perannya dalam pelaksanaan good corporate governance. Ketiga, bank harus memastikan terdapatnya check and balance system dalam pengelolaan bank. Terakhir, bank harus memiliki ukuran kinerja dari semua jajaran bank berdasarkan ukuran-ukuran yang disepakati konsisten dengan nilai perusahaan (corporate values), sasaran usaha, dan strategi bank serta memiliki rewards and punishment system. (Komite Nasional Kebijakan Corporate Governance, 2004)

\section{Tanggung Jawab (Responsibility)}

Pertama, untuk menjaga kelangsungan usahanya, bank harus berpegang pada prinsip kehati-hatian (prudential banking practices) dan menjamin dilaksanakannya ketentuan yang berlaku. Kedua, bank harus bertindak sebagai good corporate citizen (perusahaan yang baik), termasuk peduli terhadap lingkungan dan melaksanakan tanggung jawab sosial. (Komite Nasional Kebijakan Corporate Governance, 2004)

\section{Independensi (Independency)}

Pertama, bank harus menghindari terjadinya dominasi yang tidak wajar oleh stakeholder manapun dan tidak terpengaruh oleh kepentingan sepihak serta bebas dari benturan kepentingan (conflict of interest). Kedua, bank dalam mengambil keputusan harus obyektif dan bebas dari segala tekanan dari pihak manapun. (Komite Nasional Kebijakan Corporate Governance, 2004)

\section{Kewajaran (Fairness)}

Pertama, bank harus senantiasa memperhatikan kepentingan seluruh stakeholders berdasarkan azas kesetaraan dan kewajaran (equal treatment). Kedua, bank harus memberikan kesempatan kepada seluruh stakeholders untuk memberikan masukan dan menyampaikan pendapat bagi kepentingan bank serta mempunyai akses terhadap informasi sesuai dengan prinsip keterbukaan. (Komite Nasional Kebijakan Corporate Governance, 2004)

\section{Perbandingan Implementasi Prinsip Good Corporate Governance pada Bank Konvensional dan Bank Syariah}

Setiap bank, baik bank konvensional maupun bank syariah, wajib mengimplementasikan prinsip good corporate governance dalam kegiatan usahanya. Hal ini karena bank konvensional dan bank syariah merupakan lembaga intermediasi yang berfungsi menghimpun dana dari masyarakat dan menyalurkan kembali dana tersebut ke masyarakat. Pada dasarnya, implementasi prinsip good corporate governance pada bank konvensional dan bank syariah adalah 'sama', karena mengacu pada "Pedoman Good Corporate Governance Perbankan Indonesia" yang dikeluarkan oleh Komite Nasional Kebijakan Governance (KNKG).

Perbedaan yang mendasar adalah terletak pada prinsip syariah yang digunakan oleh bank syariah. Ekonomi konvensional menggunakan landasan filsafat positivism yang berdasarkan pada pengalaman dan kajian empiris, serta tidak percaya kepada petunjuk Tuhan (sekuler). Sedangkan ekonomi Islam, yang menjadi pedoman utama adalah petunjuk Allah yang ada di dalam Al-Qur'an dan Sunnah. Dengan demikian, yang menjadi pendorong bank syariah dalam mengimplementasikan prinsip good corporate governance adalah god- 
interest, yaitu dalam rangka beribadah kepada Allah.

Prinsip syariah berlandaskan pada nilainilai keadilan, kemanfaatan, keseimbangan, dan keuniversalan (rahmatanlil'alamin). Nilai-nilai tersebut diterapkan dalam pengaturan perbankan syariah. Prinsip perbankan syariah merupakan bagian dari ajaran Islam yang berkaitan dengan ekonomi. Salah satu prinsip dalam ekonomi Islam adalah larangan riba dalam berbagai bentuknya, dan menggunakan sistem antara lain prinsip bagi hasil. Implementasi prinsip good corporate governance juga bertujuan agar pegawai bank syariah berpegang pada prinsip syariah secara menyeluruh (kaffah) dan konsisten (istiqamah).

Untuk memastikan pelaksanaan prinsip good corporate governance dilaksanakan dengan baik oleh bank konvensional dan bank syariah, maka harus dilakukan pembinaan dan pengawasan oleh lembaga yang independen. Pada Pasal 29 Ayat (2) Undang-Undang Nomor 10 Tahun 1998 disebutkan bahwa pembinaan dan pengawasan bank dilakukan oleh Bank Indonesia. Pembinaan yang dilakukan Bank Indonesia antara lain mengenai aspek kelembagaan, kepemilikan dan kepengurusan (termasuk uji kemampuan dan kepatutan), kegiatan usaha, pelaporan, serta aspek lain yang berhubungan dengan kegiatan operasional bank. Pengawasan bank meliputi pengawasan tidak langsung (off-site supervision) atas dasar laporan bank dan pengawasan langsung (on-site supervision) dalam bentuk pemeriksaan di kantor bank yang bersangkutan.

Dengan disahkannya Undang-Undang Nomor 21 Tahun 2011 tentang Otoritas Jasa Keuangan, maka terhitung sejak tanggal 1 Januari 2014, pembinaan dan pengawasan bank konvensional dan bank syariah diambil alih oleh lembaga independen yang bernama Otoritas Jasa Keuangan. Pada Pasal 7 Undang-Undang Nomor 21 Tahun 2011 disebutkan bahwa Otoritas Jasa Keuangan mempunyai wewenang: (1) Pengaturan dan pengawasan mengenai kelembagaan bank, yang meliputi perizinan untuk pendirian bank, pembukaan kantor bank, anggaran dasar, rencana kerja, kepemilikan, kepengurusan dan SDM, merger, konsolidasi dan akuisisi bank, serta pencabutan izin usaha bank; dan kegiatan usaha bank. (2) Pengaturan dan pengawasan mengenai kesehatan bank, yang meliputi likuiditas, rentabilitas, solvabilitas, kualitas aset, rasio kecukupan modal minimum, batas maksimum pemberian kredit, rasio pinjaman terhadap simpanan, dan pencadangan bank; laporan bank yang terkait dengan kesehatan dan kinerja bank; sistem informasi debitur; pengujian kredit (credit testing); dan standar akuntansi bank. (3) Pengaturan dan pengawasan mengenai aspek kehati-hatian bank, meliputi manajemen risiko; tata kelola bank; prinsip mengenal nasabah dan anti pencucian uang; dan pencegahan pembiayaan terorisme dan kejahatan perbankan. (4) Pemeriksaan bank. Hal lain yang membedakan implementasi prinsip good corporate governance pada bank konvensional dan bank syariah yaitu adanya pengawasan khusus pada bank syariah yang dilakukan oleh Dewan Syariah Nasional Majelis Ulama Indonesia (MUI) dan Dewan Pengawas Syariah. Dewan Syariah Nasional MUI bertugas: (1) Menumbuhkembangkan penerapan nilai-nilai syariah dalam kegiatan perekonomian pada umumnya dan keuangan pada khususnya. (2) Mengeluarkan fatwa atas jenis-jenis kegiatan keuangan. (3) Mengeluarkan fatwa atas produk dan jasa keuangan syariah. (4) Mengawasi penerapan fatwa yang telah dikeluarkan. (Anshori, 2009)

Di dalam Undang-Undang Nomor 21 Tahun 2008 disebutkan bahwa pelaksanaan tugas dan tanggung jawab Dewan Pengawas Syariah antara lain: (1) Mengawasi proses pengembangan produk baru bank syariah. (2) Meminta fatwa kepada Dewan Syariah Nasional untuk produk baru bank syariah yang belum ada fatwanya. (3) Melakukan review secara berkala terhadap mekanisme penghimpunan dana dan penyaluran dana serta pelayanan jasa bank syariah. (4) Meminta data dan informasi terkait dengan aspek syariah dari satuan kerja bank syariah dalam rangka pelaksanan tugasnya. 


\section{SIMPULAN}

Sebagai lembaga intermediasi dan lembaga kepercayaan, dalam melaksanakan kegiatan usahanya, bank harus menganut prinsip keterbukaan (transparency), memiliki ukuran kinerja dari semua jajaran bank berdasarkan ukuran-ukuran yang konsisten dengan corporate values, sasaran usaha, dan strategi bank sebagai pencerminan akuntabilitas bank (accountability), berpegang pada prudential banking practices dan menjamin dilaksanakannya ketentuan yang berlaku sebagai wujud tanggung jawab bank (responsibility), objektif, dan bebas dari tekanan pihak manapun dalam pengambilan keputusan (independency), serta senantiasa memperhatikan kepentingan seluruh stakeholders berdasarkan azas kesetaraan dan kewajaran (fairness).

Pada dasarnya, implementasi prinsip good corporate governance pada bank konvensional dan bank syariah adalah 'sama', karena mengacu pada "Pedoman Good Corporate Governance Perbankan Indonesia" yang dikeluarkan oleh Komite Nasional Kebijakan Governance (KNKG). Perbedaan yang mendasar adalah terletak pada prinsip syariah yang digunakan oleh bank syariah. Selain dibina dan diawasi oleh Otoritas Jasa Keuangan seperti bank konvensional, bank syariah juga diawasi oleh Dewan Syariah Nasional MUI dan Dewan Pengawas Syariah yang bertugas di masing-masing bank syariah.

\section{DAFTAR RUJUKAN}

Anshori, Abdul Ghofur., 2009, Perbankan Syariah di Indonesia, Gadjah Mada University Press, Jakarta.

Mujahidin, Akhmad., 2013, Ekonomi Islam, Rajawali Pers, Jakarta.

Hermansyah, 2006, Hukum Perbankan Nasional Indonesia, Kencana Prenada Media Group, Jakarta.

Ismail, 2011, Manajemen Perbankan, Dari Teori Menuju Aplikasi, Kencana, Jakarta.

Kasmir, 2012, Bank dan Lembaga Keuangan Lainnya, Rajawali Pers, Jakarta.

Kasmir, 2012, Dasar-dasar Perbankan, Rajawali Pers, Jakarta.

Muhammad, 2005, Bank Syariah dalam Industri Perbankan Nasional, Graha Ilmu, Yogyakarta. 